\title{
Consumer values, online purchase behaviour and the fashion industry: an emerging market context
}

\author{
Ogechi Adeola \\ Lagos Business School, Lagos, Nigeria \\ Adenike Aderonke Moradeyo \\ Pan-Atlantic University, Lagos, Nigeria \\ Obinna Muogboh \\ Lagos Business School, Lagos, Nigeria, and \\ Isaiah Adisa \\ Olabisi Onabanjo University, Ago Iwoye, Nigeria
}

The fashion industry

\begin{abstract}
Purpose - This study examines consumer online purchase behaviour in the Nigerian fashion industry.

Design/methodology/approach - A cross-sectional study was conducted with a total useable sample size of 241 respondents contacted through on-site visitation. Descriptive and inferential statistics were used to test the influence of customer value on online purchase behaviour in the fashion industry.

Findings - Consumer values are categorised into terminal (happiness, love and satisfaction) and instrumental (time-saving, price-saving discount, service convenience and merchandise assortment) values. The findings show that both values have significant influence on online consumer purchase behaviour, while fashion consciousness moderates the relationship between consumer values and online purchase behaviour.

Practical implications - Online fashion retailers should focus on increasing the terminal and instrumental values of their products and making available goods that meet the needs of different generational cohorts in society.

Originality/value - Studies have examined various factors, for example, consumer values that are determinants of consumer online purchase in the fashion industry; however, there has been limited focus on the nature of fashion and online purchasing in emerging markets, particularly those in Sub-Saharan Africa.
\end{abstract}

Keywords Customer values, Online purchase behaviour, Digital retailing, Technology innovation

Paper type Research paper

\section{Introduction}

The fashion industry dates back to over a hundred thousand years, right from the availability and use of textiles by mankind (Botti, 2019). The industry, over time, has added economic and material value to humanity, evolving with society, making it a very relevant aspect of human life and also a common area of research, particularly in this technology-driven world (Bruce and Daly, 2006; Botti, 2019; Kilduff, 2005; Xue et al., 2019). Globally, the fashion industry contributes about US $\$ 3000$ bn, an estimated $2 \%$ of the world's gross domestic product (GDP) (Botti, 2019). Today, technological revolution and the Internet have enabled the establishment

(C) Ogechi Adeola, Adenike Aderonke Moradeyo, Obinna Muogboh and Isaiah Adisa. Published in PSU Research Review. Published by Emerald Publishing Limited. This article is published under the Creative Commons Attribution (CC BY 4.0) licence. Anyone may reproduce, distribute, translate and create derivative works of this article (for both commercial and non-commercial purposes), subject to full attribution to the original publication and authors. The full terms of this licence may be seen at http:// creativecommons.org/licences/by/4.0/legalcode

Received 25 April 2021 Revised 1 June 2021 Accepted 13 August 2021

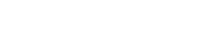


of online fashion retail systems to displace aspects of the traditional store patronage (Johnstone et al., 2013; Kautish and Sharma, 2018; Pantano and Viassone, 2015).

The term "fashion" is a concept that is widely accepted by committees, class or groups of people and is directly affected by marketing factors, such as low predictability, high impulse purchase, short-life cycle and the high volatility of market demand (Fernie and Sparks, 1998; Bhardwaj and Fairhurst, 2010).

Digital retailing in the fashion industry has gained prominence, providing ample opportunities for marketers to reach out to different generational cohorts (i.e. generations X, $\mathrm{Y}$ and Z) (Pentecost and Andrews, 2010). Generational cohort is a theoretical approach to understanding the diverse group of individuals in a society. The term is used to describe individuals who share similar political, social, cultural and economic events during their childhood (Fernández-Durán, 2016). The most widely used categorisation is Gen X, Y and Z (Sima, 2016). Individuals who fall into these classifications are considered to share similar behaviour, perceptions of reality, values and consumption patterns, which must be understood from a marketing standpoint (Fernández-Durán, 2016; Liang and Xu, 2018; Mahmoud et al., 2021; Sima, 2016; Tan et al., 2019). For example, individuals in Gen X (19651981) are regarded as digital immigrants while Gen Y (1982-1999) and Gen Z (2000-2012) are regarded as digital natives (Mahmoud et al., 2021). To contextualise the distribution of consumers in the fashion market, this classification must be well understood.

Retail digitisation has changed the process of shopping for consumers and the process of selling for organisations in the fashion industry by providing convenient and affordable services (Hagberg et al., 2016; Kautish and Sharma, 2018; Renko and Druzijanic, 2014). Consumers' desire to shop for clothing online has, however, been hindered by challenges of "fit" and "size" of cloths (Miell et al., 2018). There have been several studies (e.g. Loker et al., 2004, 2008; Song and Ashdown, 2012; Kim and LaBat, 2013; Beck and Crié, 2018) that focused on providing solutions to the challenges that can impede the benefits of online fashion retailing for businesses, shoppers, and generally hinder the growth of the industry.

These challenges have negatively influenced consumers' perception of online purchases in the fashion industry, especially with clothing purchase. Digital "fit" and "sizing" technologies have been introduced to address this challenge and give customers the needed satisfaction in their online fashion purchases in developed nations (Miell et al., 2018). Online purchase is gaining prominence in Nigeria (Aminu, 2013; Usman and Kumar, 2020), but the rate and pace of online fashion (apparel) purchase have been low despite having a large population of Internet users (Falode et al., 2016). Falode et al., investigated online and offline shopping motivation of apparel consumers in Ibadan, Nigeria and found that consumers prefer offline purchase of apparel to online. This is quite worrying as Nigeria has an active online population which offers fashion organisations enormous opportunities (Falode et al., 2016). Hence, understanding the factors that will engender the consumer's online purchase in the fashion industry is sacrosanct to the sustainability of the online fashion space in Nigeria.

Extant studies have attempted to provide predictive direction regarding what influences consumers' online purchases in the fashion industry. For example, Schmidt et al. (2015) posit that what consumers see and hear online, influences their buying behaviour. Pentecost and Andrews (2010) established that gender influences the rate of purchase and that females purchase more items in the fashion industry than their male counterparts. Pentecost and Andrews also found that Gen Y consumers have higher purchase frequency and impulse buying than other generational cohorts. Kautish and Sharma (2018) examined consumer values, fashion consciousness and behavioural intentions in the online fashion retail sector and found a significant relationship between consumer values, fashion consciousness and behavioural intention of the consumers in India. Their study was conducted to highlight the basic factors that influence consumer purchase and patronage of online retailing in the country's fashion industry. The authors identified three variables that determine 
the consumer's online behaviour: consumer values, fashion consciousness and behavioural intentions.

Generally, countries in Africa are known for their distinct socio-cultural values, which influence their fashion behaviour (Aminu, 2013; Falode et al., 2016). The role of socio-cultural values on consumer purchase behaviour has also been explored (see Agnihotri and Bhattacharya, 2019; Ansari, 2018; Craig and Douglas, 2006; Kacen and Lee, 2002; Koon et al., 2020; Nwankwo et al., 2014; Pepper et al., 2009; Tendai and Crispen, 2009); however, there is a dearth of studies on consumer online purchase behaviour, in the fashion industry, with reference to sub-Saharan Africa. A key country in this region is Nigeria, known for its multiethnicity and large population. The country's median age is 18.4 years, which indicates the propensity of a technology-driven youthful population (Varrella, 2020). With the challenge of "fit" and "size" and patronage of online fashion space in Nigeria (Falode et al., 2016; Ogbuji and Udom, 2018), this study assesses consumer purchase behaviour in online fashion retailing of an emerging market, particularly in a technology-driven society. Following Kautish and Sharma's (2018) study, we adopt the variables - values, fashion consciousness and behavioural intention to purchase - as predictors of online consumer purchase behaviour in the Nigerian fashion industry.

\section{Theoretical framework}

\section{Theory of planned behaviour}

This paper adopts the theory of planned behaviour (TPB) by Azjen $(1985,1991)$ to explain the purchase and patronage of online fashion retailing. Azjen (1991) asserts that an individual's behaviour is not spontaneous but rather is influenced and determined by various factors, such as intention, social norm and perceived control over certain phenomena. TPB is an extension of the theory of reasoned action (TRA) (Azjen and Fishbein, 1980; George, 2004). The TRA proposed that intention is crucial in exhibiting certain behaviours, and it is measured by attitude and subjective norms (Hagger, 2019). The theory focused on explaining behaviours within the individual's control, and the scope did not capture explanations on why individuals are not in total control of some of their behaviours, and this led to TPB. Azjen extended TRA with the propositions of the TPB and included the construct of perceived behavioural control to explain behaviours beyond the control of the individual (Hagger, 2019).

According to George (2004), the attitude towards a target behaviour and the subjective norms surrounding it determine intention. Several studies have applied the assumptions of TPB to purchase behaviour (Arora and Sahney, 2018; Conner, 2020; George, 2004; Verma and Chandra, 2018) and also in studies on Internet purchasing behaviour (i.e. Battacherjee, 2000; George, 2002, 2004; Jarvenpaa and Todd, 1997a, b; Khalifa and Limayem, 2003; Limayem et al., 2000; Pavlou, 2002; Song and Zahedi, 2001; Singh and Srivastava, 2019; Suh and Han, 2003; Tan and Teo, 2000; Verma and Chandra, 2018). The three antecedents of onlinepurchasing behaviour are measured and defined on the premise of TPB (Ham et al., 2015). These include attitude and intention (Do I want to do that?), subjective norms (Do others want me to do that?) and perceived control (Do I have the necessary ability to do that?).

Azjen (1991) proposes that intention is determined by an individual's attitude, subjective norms and perceived behavioural control. Attitude can either be positive or negative, and it is influenced by an individual's beliefs, which, in turn, inform the norms. Azjen (1991) adds that an individual's possession of resources and opportunities needed to engage in the behaviour would influence whether the individual will exhibit such behaviour. In other words, it is not sufficient to have intentions to purchase; individuals must also have the ability to purchase the product. For example, two individuals might have the same level of intention and belief in purchasing a particular product, but the one with the resources to purchase the product is more likely to make the purchase decision.
The fashion industry 
In the context of this study, behaviour is determined by intentions and beliefs (social norms) that align with the individual's values. Individuals will act in calculative ways, such that decisions are made based on the most favourable outcome. This paper hypothesises that consumers' values (terminal and instrumental values) and consumers' fashion consciousness are factors that determine their online purchases in the fashion industry. This implies that in an emerging market, despite the challenges of fit and size of apparels bought online (Kaushik et al., 2020), consumers' instrumental values, terminal values and fashion consciousness will stimulate purchase using the same medium. TPB is, therefore, adopted to explain and predict consumer online purchase behaviour in the fashion industry and in an emerging market; this is premised on the tenets of the theory that consumers' values (instrumental, terminal) and fashion consciousness will determine consumers' purchase in the online fashion industry.

\section{Technology and the fashion industry}

The retail business is experiencing continuous changes due to the dynamics in taste, innovation and consumer behaviour in the market (Kennedy et al., 2019; Suzuki and Park, 2018; Tendai and Crispen, 2009). The fashion industry, which is one of the oldest industries in the history of mankind, has been very dynamic, evolving according to the tastes, trends and needs of society. Xue et al. (2019) emphasise that retailers must understand how to use technology to facilitate consumer purchase behaviour in local and global markets of this era. Xue et al. (2019) project that proper investment in electronic retailing would enhance the business performance of retailers, sustain their competitive advantage and attract a larger population to the electronic market, if the purchase behaviours of consumers within the markets are understood. The fashion industry has evolved and imbibed the online retailing system to attract the attention of the majority in the market. As society is becoming more technology-driven, the fashion industry must position itself in line with this trend; however, some studies show that challenges emanating from online fashion commodities, like apparels, have negatively affected rather than boost retail sales (Bonetti et al., 2018; Hope-Allwood, 2016; Xue et al., 2019).

Therefore, having a technology-driven retail strategy without understanding or paying attention to factors that influence consumer purchase behaviour will result in negative sales outcome, for consumers are driven by social and psychological factors in their purchase intention. Niemeier et al. (2013) as well as Xue et al. (2019) found hedonic factors, convenience (friendly-user interface and easy process) and entertainment as determinants of consumers' purchase of virtual products. Contributing to the array of knowledge on consumer purchase of virtual products, consumer values, fashion consciousness and behavioural intention are tested in this study.

\section{Consumer values, fashion consciousness and behavioural intentions in the online fashion retail sector}

Kautish and Sharma (2018) studied consumers' behavioural intention in the online retail fashion sector. In the study, consumers' values and fashion consciousness were used to determine behavioural intention in patronising online fashion retail organisations. The authors found that the ability of the commodity to communicate value to the customers determines whether they will purchase a fashion apparel. The results also indicated that consumers' values significantly influence fashion consciousness and intention to purchase. In their study, fashion consciousness is described as an individual's involvement with fashion trends, which makes apparel purchase convenient. Customer value is categorised into two: terminal value and instrumental value. Terminal value describes a customer's experience and feelings from purchasing a commodity, while instrumental values are core characteristics that the individual possesses, which are expected to be reflected in the commodity purchased 
(Kautish and Sharma, 2018). Key instrumental values that influence consumer purchase of online apparels, as discussed by Kautish and Sharma (2018), are time-saving, price-saving and discount, service convenience and merchandise assortment. The availability of these values in online apparel is expected to stimulate consumer purchase (Bridges and Florsheim, 2008; Matic and Vojvodic, 2017; Scarpi, 2012). With this background, we propose that

H1. Instrumental value influences consumer online purchase behaviour in emerging markets.

Another aspect of customers' values that is examined is the terminal value; this, as measured by Kautish and Sharma (2018), is the psychological implication of a commodity on an individual. Happiness, love and satisfaction from the purchase of a commodity are measures of terminal value. Relatedly, Allen et al. (2002) describe terminal value as arising from freedom, comfortable life, satisfaction and love. It is expected that when a consumer perceives an online purchase to provide the above mentioned values, positive behaviour will be stimulated; therefore, we make a second proposition that

H2. Terminal values influence consumer online purchase behaviours in an emerging market

Scholars have extensively examined the likely factors that influence consumers' fashion consciousness. Mulyanegara (2011) and Casidy (2012) state that the personality of consumers could be a determinant of their fashion consciousness. Fashion consciousness was defined by Fernandes (2013) as the extent to which a consumer is carried away with trending fashion styles and clothing. It refers, thus, to the degree of participation and involvement with styles and clothing in the apparel market (Babin and James, 2010; Kautish and Sharma, 2018). Furthermore, it is believed that because of the apparent short life cycle of apparels, most consumers dislike investing much money in purchasing wears at ridiculously high prices. Fernandes (2013), therefore, submits that customers who are not so carried away with fashion are prone to purchase counterfeit apparels. Based on this submission, we propose the third hypothesis:

H3. Fashion consciousness influences consumer online purchase behaviour in the fashion industry

Based on the paucity of studies that have examined the influence of customer values on fashion consciousness and the submissions of Mulyanegara (2011) and Casidy (2012) that characteristics of the buyer determine purchase, a fourth hypothesis is proposed to test this relationship. An interaction between customer values and consumer purchase behaviour can therefore be proposed with a moderating role of consumers' fashion consciousness. Factors such as world views, personal norms, self-concept and environmental context have been previously found to influence consumer purchase behaviour (Rohan, 2000; Pepper et al., 2009). Pepper et al. (2009), however, suggested that it is not sufficient to determine consumer purchase behaviour based on values without considering different mediating and moderating factors, unless general behaviours are examined and not specific ones. The authors further suggested that it is important to compare different factors that influence consumer behaviour in order to determine the strength of the purchase factors. Our fourth hypothesis, thus, is stated as follows:

H4. The relationship between consumer values (terminal and instrumental) and consumer online purchase behaviour is moderated by consumers' fashion consciousness

\section{Methods}

Research sample

We employed a cross-sectional design and surveyed 282 individuals through convenience sampling. The data collection method yielded a useable total of 241 survey reports through
The fashion industry 
onsite visitation, representing a response rate of $88.5 \%$, which is considered adequate. The remaining 41 survey reports were rejected due to incomplete information. The survey questionnaire contained close-ended questions and was administered to the respondents in August 2019. The study was conducted in an environment comprising both students and the working class, where a major public university in Lagos, Nigeria, is situated. The demographic characteristics of respondents are as follows: $52.3 \%$ of the respondents are students; $13.3 \%$ are unemployed; $2.90 \%$ are self-employed and the remaining $31.5 \%$ constitute other professions (Table 1). Most of the respondents in the study fall within Generation Y (21-30 years, $45.6 \%$; 31-40 years, $21 \%$ ) and Z (Below 20, 28\%) category. The descriptive statistics and correlation of the constructs are provided in Table 2.

\section{Measures}

To ensure high content validity, all the measurement scales used for the consumer values, fashion consciousness and online consumer purchase behaviour were adopted from extant literature (Kautish and Sharma, 2018). The survey asked respondents to indicate on a 7-point Likert scale, ranging from 1 = "strongly disagree" through to 7 = "strongly agree", the extent to which each statement applied to them.

Control variables. We controlled for four variables in the analyses to account for other factors that were not captured in the research but could affect customer online purchase behaviour in Nigeria. These control variables include age of respondent, educational qualification, monthly income and online purchase frequency.

\begin{tabular}{|c|c|c|}
\hline $\mathrm{S} / \mathrm{N}$ & Characteristics of respondents & Percentage \\
\hline \multirow[t]{6}{*}{1} & Age & \\
\hline & Below 20 years & 28.0 \\
\hline & $21-30$ years & 45.6 \\
\hline & $31-40$ years & 21.0 \\
\hline & $41-50$ years & 5.4 \\
\hline & Above 50 years & - \\
\hline \multirow[t]{5}{*}{2} & Occupation & \\
\hline & Student & 52.3 \\
\hline & Unemployed & 13.3 \\
\hline & Self-employed & 2.90 \\
\hline & Other professions & 31.5 \\
\hline \multirow[t]{6}{*}{3} & Monthly income & \\
\hline & $<=N=25,000$ & 27.0 \\
\hline & $>=N=25,000-<=N=50,000$ & 39.8 \\
\hline & $>=N=50,000-<=N=100,000$ & 19.1 \\
\hline & $=N=101,000-=N=150,000$ & 4.1 \\
\hline & $>=N=150,000$ & 10.0 \\
\hline \multirow[t]{4}{*}{4} & Educational qualification & \\
\hline & Secondary school leaving certificate & 21.6 \\
\hline & Diploma and undergraduate degree & 59.7 \\
\hline & Masters and or $\mathrm{PhD}$ degree & 18.7 \\
\hline \multirow[t]{5}{*}{5} & Online purchase frequency & \\
\hline & Once a month & 28.6 \\
\hline & Once in 2 months & 8.8 \\
\hline & Once in 3 months & 22.3 \\
\hline & Once in 4 months & 40.3 \\
\hline
\end{tabular}

Table 1.

Demographic characteristic of respondents
Age

21-30 years $\quad 45.6$

$31-40$ years 21.0

$41-50$ years $\quad 5.4$

Occupation

Student

52.3

2.90

31.5

Monthly income

$<=N=25,000$

27.0

4.1

10.0

1.6

$\begin{array}{ll}\text { Diploma and undergraduate degree } & 59.7 \\ \text { Masters and or PhD degree } & 18.7\end{array}$

Online purchase frequency

Once in 3 months

Once in 4 months $\quad 40.3$ 


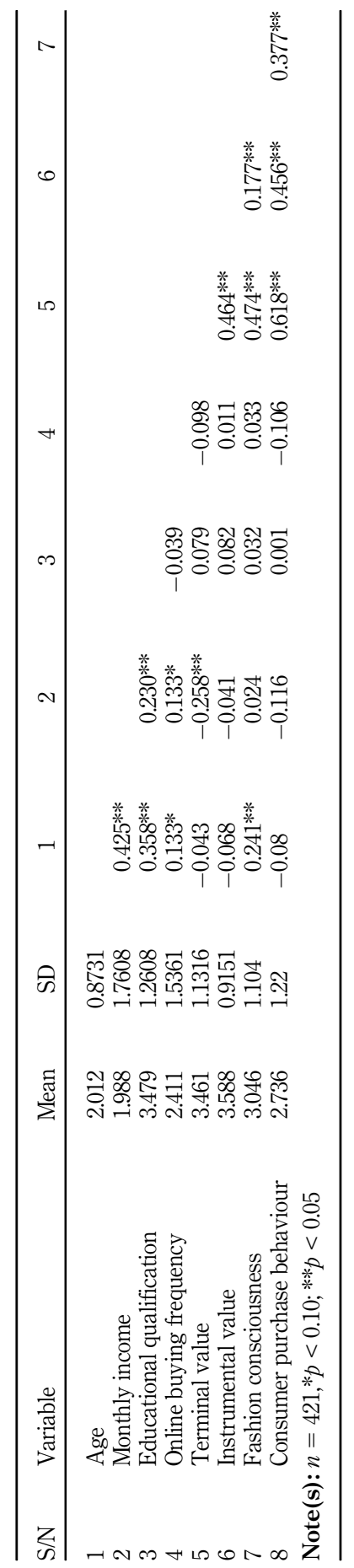

The fashion industry 
PRR

Figure 1.

The model above represents the direct effects models (Hypotheses 1, 2,3) and the moderation model (Hypothesis 4)
Scale validity and reliability. The Cronbach alpha reliability test $(\alpha)$, which shows internal consistency for each item that makes up a construct is as follows: consumer value has $\alpha$ value of 0.70 ; fashion consciousness has $\alpha$ value of 0.72 and consumer online purchase behaviour has $\alpha$ value of 0.80 . These Cronbach alpha values are all above 0.7 , which is the recommended minimum acceptable level (Hair et al., 1998). Confirmatory factor analyses (CFAs) of the adopted measures which confirm the discriminant validity are as follows: normed chi-square value $\left(\chi^{2}=537.48 ; \mathrm{df}=129\right)$, the fit indices Non-Normed Fit Index $(\mathrm{NNFI})=0.70$, Normed Fit Index $(\mathrm{NFI})=0.70$, Goodness of Fit $(\mathrm{GFI})=0.80$, Comparative Fit Index $(\mathrm{CFI})=0.74, p$ value $=0.00000$ and Root Mean Square Error $($ RMSEA $)=0.115$. The CFA results confirmed the discriminant validity of the constructs. Table 2 shows the means, standard deviations and correlations of the variables. The $\left(\chi^{2} / \mathrm{df}\right)$ value for the model is 4.2 , which is within the acceptable range of 2-5 (MacCallum et al., 1999; Marsh et al., 1988, 1998; Kautish and Sharma, 2018).

\section{Analysis and results}

The following regression model was used to estimate the consumer online purchase behaviour influence of the two independent constructs: consumer value and fashion consciousness:

$$
Y_{i}=\beta_{0}+\beta_{1} C V+\beta_{2} F C+\beta_{3} C V F C+e_{i}
$$

The subscript $i$ denotes each respondent $(i=1, \ldots, 241)$. $Y$ is the dependent variable (Consumer online purchase behaviour). CV represents the vector for the variants, terminal and instrumental values, FC represents the vector for fashion consciousness, CVFC represents the vector for the moderating effects and $e_{i}$ is the error term. $\beta_{1}-\beta_{3}$ represent the parameters of the coefficients. Figure 1 shows the research model.

Multiple regression analysis was carried out using the hierarchical method (Cohen and Cohen, 1983). In this case, the independent variables were sequentially introduced, one after the other. The hierarchical regression analysis was carried out using six separate multiple regression analyses, as shown in Table 3. In the first regression model, all the control variables were included. In the second regression model, consumer terminal value was regressed on the consumer online purchase behaviour and the control variables. In the third regression model, the instrumental value was regressed on the consumer online purchase behaviour and the control variables. In the fourth regression model, consumer values (terminal and instrumental values) were regressed on the consumer online purchase behaviour and the control variables. Finally, the interaction terms and consumer values (terminal and instrumental values) were regressed on the consumer online purchase behaviour and the control variables.

Overall, the four hypotheses are supported, as indicated in Table 3. From model 1, none of the control variables is significant. From model 2 , the results show that terminal value is significantly positively related to consumer online purchase behaviour $(\beta=0.633$ at $p<0.01)$, thus, supporting H1; all the control variables are not significant. From model 3, the results show that instrumental value is significantly positively related to consumer online purchase behaviour $(\beta=0.451$ at $p<0.01)$, thus supporting $\mathrm{H} 2$; all the control variables are not

Direct Effects and Moderating Effect Model

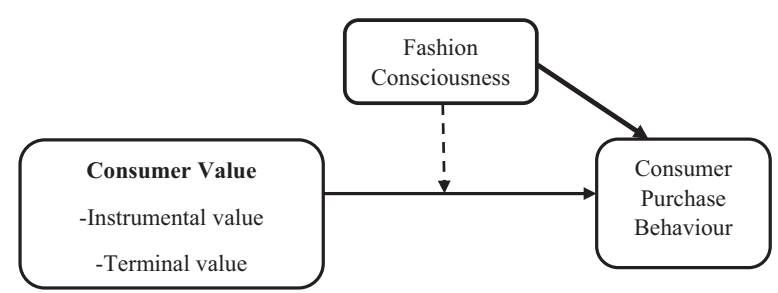




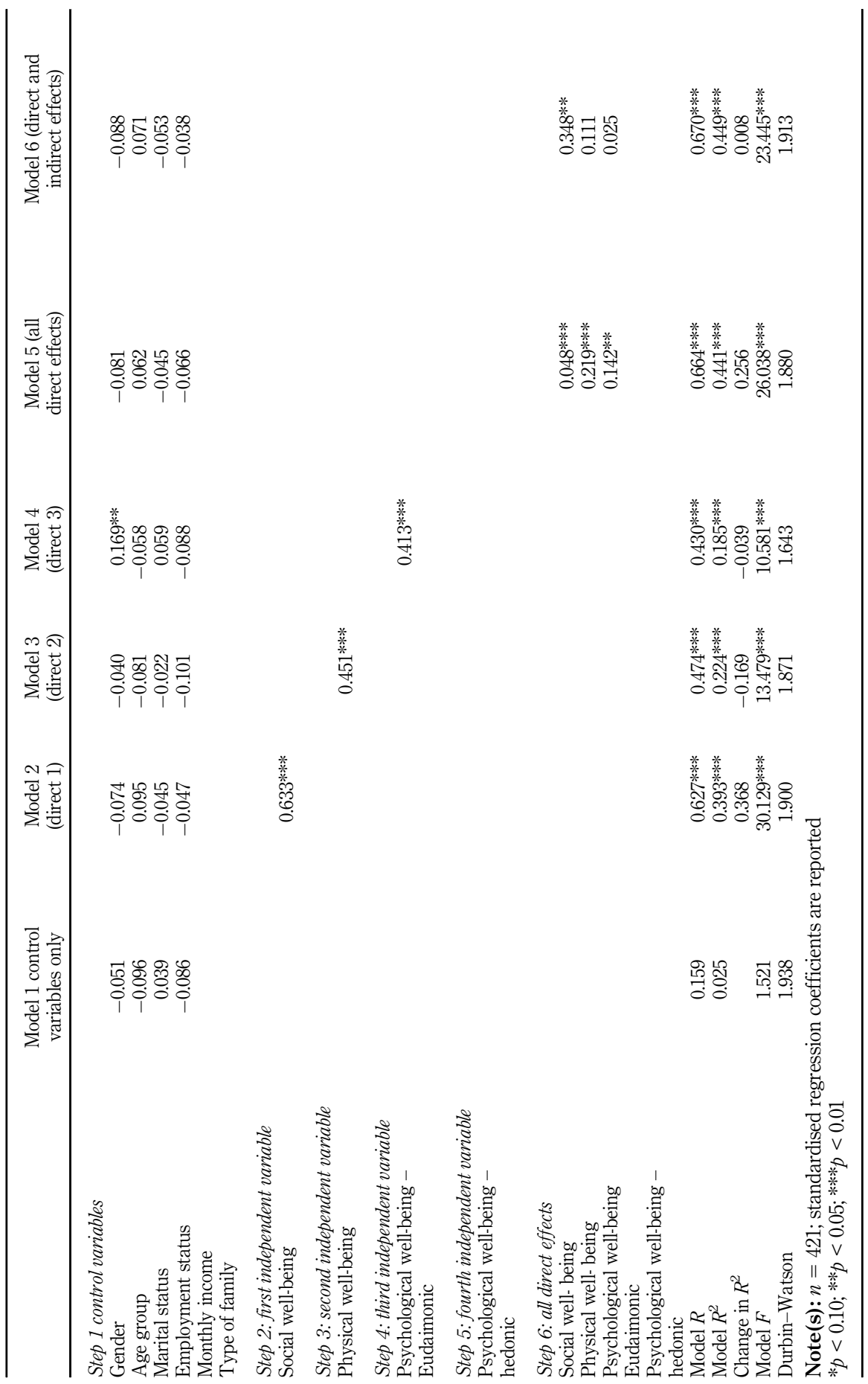

The fashion industry 
significant. From model 4, the results show that fashion consciousness is significantly positively related to consumer online purchase behaviour $(\beta=0.413$ at $p<0.01)$, thus supporting H3; almost all the control variables are not significant, except the age of respondents, which is significant $(\beta=-0.169$ at $p<0.05)$. From model 5 , the results show that terminal value is significantly positively related to consumer online purchase behaviour $(\beta=0.048$ at $p<0.01)$, thus also supporting H1. Instrumental value is significantly positively related to consumer online purchase behaviour $(\beta=0.219$ at $p<0.01)$, thus also supporting H2.

Fashion consciousness is significantly and positively related to consumer online purchase behaviour $(\beta=0.142$ at $p>0.05)$, thus also supporting H3. All the control variables are found to be insignificant. From model 6 , the results show that the interaction term (terminal value $\times$ instrumental value $\times$ fashion consciousness) is significantly positively related to consumer online behaviour, thus supporting H4. Instrumental value is not significant, whereas terminal value is significantly related to consumer online purchase behaviour. Fashion consciousness is not significantly related to consumer online purchase behaviour.

All the control variables are found to be insignificant. From model 6, the interaction between consumer value and fashion consciousness accounted for significantly more variance than just consumer value and fashion consciousness alone; $R^{2}$ change $=0.008$, $p<0.01$, indicating that there is potentially significant moderation between consumer value and fashion consciousness on consumer online purchase behaviour. The Durbin-Watson ranges from 1.6-1.9, which are approximately 2, and shows no evidence of autocorrelation (Gujarati, 2003). The overall statistical measures, such as $\left(R^{2}, R, F\right.$ and $p$-value) indicate the adequacy of the model (see Table 3).

\section{Discussions and implication}

The role of consumer values in influencing online purchase has been documented in the literature (Limayem et al., 2000; Nwankwom et al, 2014; Kautish and Sharma, 2018). However, very few studies have examined the role of technological innovation in influencing customer value towards online purchase, especially as related to the fashion industry. Kautish and Sharma (2018) examined consumer values, fashion consciousness and behavioural intentions in India's online fashion retail sector and suggested that similar studies should be conducted in emerging economies with diverse cultures. This study, thus, fills this gap by examining consumer values and purchase in the fashion industry through technological platforms in emerging markets, like Nigeria.

Consumer values were grouped into instrumental and terminal values to illustrate the practical implications of the study. The first hypothesis examined the influence of instrumental value on consumer online purchase behaviour in an emerging market, and the result shows that there is a positive significant relationship between instrumental values and online purchase of fashion apparels. This implies that purchasing apparel online saves consumers' time, cost of purchase, convenience, discount in services received and it offers varieties of goods to choose and buy. In other words, key factors that attract and influence the purchase of fashion items online using technological innovation are the convenience, low cost, discount and variety of commodities offered by online stores. This result supports the theoretical proposition by Azjen (1991) that behaviours of individuals are influenced by calculative permutations on the cost and benefits of their actions. Consequently, intentions become actions when it is perceived that the action has more benefit than cost. This finding also supports the observations of Kautish and Sharma (2018) that instrumental values to be derived by consumers in the purchase of a commodity online will influence their purchase decision.

The second hypothesis on the influence of terminal values and consumer online purchase behaviour in an emerging market reveals a significant and positive relationship between terminal value and consumer online purchase behaviour. This implies that happiness, love and satisfaction are consumers experience when they purchase fashion apparels online. In addition, customers perceive a sense of freedom and comfort when they successfully make 
online purchases. This also supports the submission of Allen et al. (2002) as well as Kautish and Sharma (2018) that terminal value reward from online purchase of a product influences consumer purchase. Online stores, hence, must ensure that their products provide ease of purchase and are low cost and also that the apparels reflect the desires of the customers, such that they provide comfort, satisfaction and happiness when worn.

The third hypothesis examines the influence of fashion consciousness on consumer online purchase behaviour in the fashion industry, and the result shows a significant and positive relationship between fashion consciousness and purchase behaviours. This implies that students, professionals, the employed and unemployed in emerging markets like Nigeria, support and are mindful of fashion trends; the result also showed that students are more interested in fashion trends than the unemployed and self-employed; this result might be associated with the fact that Gen $\mathrm{Y}$ and $\mathrm{Z}$ consumers are the most represented in this study. This result supports the observations of Babin and James (2010), Fernandes (2013), Kautish and Sharma (2018) that fashion consciousness influences the decision to purchase apparels and other related fashion items online. Kautish and Sharma's (2018) submitted that Gen Y consumers have a higher purchase frequency and impulse buying than other generational cohorts. However, this study extends knowledge from the work of Kautish and Sharma (2018), which was focused on students to show that it is not only this category of individuals who are fashion-conscious but also professionals, the self-employed and even the unemployed in emerging markets, like Nigeria.

The fourth hypothesis tested the moderation of customer values (terminal and instrumental) and online purchase behaviour by fashion consciousness, and the result shows that fashion consciousness moderates the extent to which consumers' values influence their purchase behaviour. A society with a high rate of fashion-conscious individuals will purchase fashion apparels online more than a society with less fashion-conscious people. In addition, it shows that an individual's consciousness for fashion plays a primary role in the online purchase of fashion apparels and other fashionable items.

Additional findings in the study reveal that terminal value has a greater influence on online consumer purchase of fashion apparel. This is indicated by its higher coefficient score (0.633) compared to the scores for the instrumental value (0.451) and fashion consciousness (0.413) (see Table 3). This shows that happiness, love, satisfaction, a sense of freedom and comfort derived from online purchase of fashion apparels influence customers' behaviour more than instrumental values (ease of purchase, cost, convenience, discount and product varieties). Interestingly, these findings do not support the observations of Kautish and Sharma (2018) in India, which indicated that instrumental value has a greater influence on consumer purchase. The reverse is the case in this study, as the terminal value reflects the highest coefficient among the two constructs. Nigerians in the study were more interested in the terminal value obtained from the purchase of fashion apparels online, as opposed to customers in India, which might be due to their social and cultural differences.

\section{Implication for practice}

The findings from this study have both business and technology-use implications. First, organisations and businesses in the fashion industry must continue to implement innovative and technological ideas on how to provide customers with the values that appeal to them from the online purchase of apparels as this has proven to be a key factor influencing customers' purchase. Consumers in this study are influenced by the convenience and time efficiency of purchase, cost-effectiveness, discount and availability of varieties; hence, managers, business owners and app developers for the fashion market must ensure that their services take into consideration all of these factors for online purchase to be continually stimulated.

Additionally, managers and app developers must understand the kind of apparels that conform to consumers' satisfaction and design, such apparels to meet this need, as this is also 
paramount to stimulate purchases. Consumers in the Nigerian fashion market are conscious of apparels that give them comfort, a sense of love, happiness and are trendy; therefore, online fashion retailers must have in stock apparels that possess these characteristics. In addition, the targeted audience should not be students or the younger generation alone, as this study has shown that the larger Nigerian populace is fashion conscious. Business owners should have apparels that cut across generations X, Y and Z; they should ensure that there are various offerings to capture different population classifications in the market, thereby meeting all needs. Businesses can focus more on generation $\mathrm{Y}$ and $\mathrm{Z}$ as they are the most populous in emerging markets and are more used to digital innovations. In spite of this, generation $\mathrm{X}$ must still be captured in their product offerings and designs.

The focus should be on increasing terminal values (happiness, love and satisfaction, a feeling of freedom and comfort) of fashion apparels purchased. Instrumental values (ease of purchase, cost, convenience, discount and product varieties) values are important to the Nigerian market; however, there is a preference for clothes that satisfy more terminal values.

\section{Limitations and direction for future research}

The study covered consumer values, fashion consciousness and online purchase in the fashion industry in an emerging market - Nigeria. This study is limited to the online fashion (apparel) market and did not take into consideration other viable sectors. Hence, future studies can fill this gap. Other markets, for instance, electronics and automobiles, can be examined in future studies to extend the knowledge of online purchasing and the impact of technological innovations.

Through the lens of a cross-sectional methodology and quantitative techniques, convenience sampling was used to select respondents from a mixed population of students, working-class professionals, the self-employed and unemployed within a multicultural and industrial environment, Lagos.

Future studies can consider using random sampling techniques, triangulate their methods and expand the geographical coverage of the sample as non-attention to these factors can be considered a limitation of the study.

\section{References}

Agnihotri, A. and Bhattacharya, S. (2019), "Unethical consumer behavior: the role of institutional and socio-cultural factors”, Journal of Consumer Marketing, Vol. 36 No. 1, pp. 124-135, doi: 10.1108/ JCM-02-2017-2093.

Allen, M.W., Hung Ng, S. and Wilson, M. (2002), "A functional approach to instrumental and terminal values and the value-attitude-behaviour system of consumer choice", European Journal of Marketing, Vol. 36 Nos 1/2, pp. 111-135.

Aminu, S.A. (2013), "Challenges militating against adoption of online shopping in retail industry in Nigeria", Journal of Marketing Management, Vol. 1 No. 1, pp. 23-33.

Ansari, Z.A. (2018), "Socio cultural influences on online shopping behaviour", Journal of Business and Retail Management Research, Vol. 13 No. 2, pp. 255-263.

Arora, S. and Sahney, S. (2018), "Antecedents to consumers' showrooming behaviour: an integrated TAM-TPB framework”, Journal of Consumer Marketing, Vol. 35 No. 4, pp. 438-450, doi: 10.1108/ JCM-07-2016-1885.

Azjen, I. (1985), "From intentions to actions: a theory of planned behavior", in Kuhl, J. and Beckman, J. (Eds), ActionControl: from Cognition to Behavior, Springer, Heidelberg, pp. 11-39.

Azjen, I. (1991), "The theory of planned behavior", Organizational Behavior and Human Decision Processes, Vol. 50 No. 2, pp. 179-211.

Azjen, I. and Fishbein, M. (1980), Understanding Attitudes and Predicting Social Behavior, PrenticeHall, Englewood Cliffs, NJ. 
Babin, B.J. and James, K.W. (2010), "A brief retrospective and introspective on value", European Business Review, Vol. 22 No. 5, pp. 471-478.

Battacherjee, A. (2000), "Acceptance of e-commerce services: the case of electronic brokerages", IEEE Transactions on Systems, Man, and Cybernetics Part A: Systems and Humans, Vol. 30 No. 4, pp. $411-420$.

Beck, M. and Crié, D. (2018), "I virtually try it I want it! Virtual Fitting Room: a tool to increase online and offline exploratory behavior, patronage and purchase intentions", Journal of Retailing and Consumer Services, Vol. 40, pp. 279-286.

Bhardwaj, V. and Fairhurst, A. (2010), "Fast fashion: response to changes in the fashion industry", The International Review of Retail, Distribution and Consumer Research, Vol. 20 No. 1, pp. 165-173.

Bonetti, F., Warnaby, G. and Quinn, L. (2018), "Augmented reality and virtual reality in physical and online retailing: a review, synthesis and research agenda", in Augmented Reality and Virtual Reality, Springer, Cham, pp. 119-132.

Botti, R. (2019), "Fashion sector outsourcing to African countries: taking advantage of low-cost labor?", in Moreno-Gavara, C. and Jiménez-Zarco, A. (Eds), Sustainable Fashion. Palgrave Studies of Entrepreneurship in Africa, Palgrave Macmillan, Cham.

Bridges, E. and Florsheim, R. (2008), "Hedonic and utilitarian shopping goals: the online experience", Journal of Business Research, Vol. 61 No. 4, pp. 309-314.

Bruce, M. and Daly, L. (2006), "Buyer behaviour for fast fashion”, Journal of Fashion Marketing and Management, Vol. 10 No. 3, pp. 329-344.

Casidy, R. (2012), "An empirical investigation of the relationship between personality traits, prestige sensitivity, and fashion consciousness of Generation Y in Australia", Australasian Marketing Journal (AMJ), Vol. 20 No. 4, pp. 242-249.

Cohen, J. and Cohen, P. (1983), Applied Multiple Regression/Correlation Analysis for the Behavioral Sciences, Erlbaum. United States, Hillsdale, NJ.

Conner, M. (2020), "Theory of planned behavior", in Handbook of Sport Psychology, pp. 1-18.

Craig, S.C. and Douglas, S.P. (2006), "Beyond national culture: implications of cultural dynamics for consumer research", International Marketing Review, Vol. 23 No. 3, pp. 322-342.

Falode, B.O., Amubode, A.A., Adegunwa, M.O. and Ogunduyile, S.R. (2016), "Online and offline shopping motivation of apparel consumers in Ibadan metropolis, Nigeria", International Journal of Marketing Studies, Vol. 8 No. 1, pp. 150-160.

Fernandes, C. (2013), "Analysis of counterfeit fashion purchase behaviour in UAE", Journal of Fashion Marketing and Management: An International Journal, Vol. 17 No. 1, pp. 85-97.

Fernández-Durán, J.J. (2016), "Defining generational cohorts for marketing in Mexico", Journal of Business Research, Vol. 69 No. 2, pp. 435-444.

Fernie, J. and Sparks, L. (1998), "1 Retail logistics: changes and challenges", in Logistics and Retail Management: Emerging Issues and New Challenges in the Retail Supply Chain, Vol. 1.

George, J.F. (2002), "Influences on the intent to make Internet purchases", Internet Research, Vol. 12 No. 2, pp. 165-180.

George, J.F. (2004), “The theory of planned behaviour and Internet purchasing”, Internet Research, Vol. 14 No. 3, pp. 198-212.

Gujarati, D.N. (2003), Basic Econometrics, 4th ed., McGraw-Hill, Boston.

Hagberg, J., Sundstrom, M. and Egels-Zandén, N. (2016), "The digitalisation of retailing: an exploratory framework", International Journal of Retail and Distribution Management, Vol. 44 No. 7, pp. 694-712.

Hagger, M.S. (2019), "The reasoned action approach and the theories of reasoned action and planned behavior", in Dunn, D.S. (Ed.), Oxford Bibliographies in Psychology, Oxford University Press, New York, NY, doi: 10.1093/OBO/9780199828340-0240.
The fashion industry 
Hair, J.F., Anderson, R.E., Tatham, R.L. and Black, W.C. (1998), Multivariate Data Analysis, 5th ed., Prentice-Hall, Englewood Cliffs, New Jersey, 07632.

Ham, M., Jeger, M. and Frajman Ivković, A. (2015), "The role of subjective norms in forming the intention to purchase green food", Economic Research-Ekonomska Istraživanja, Vol. 28 No. 1, pp. 738-748.

Hope Allwood, E. (2016), "Is virtual reality the future of the fashion show?", available at: https://www. dazeddigital.com/fashion/article/30163/1/is-virtual-reality-the-future-of-the-fashion-show.

Jarvenpaa, S.L. and Todd, P.A. (1997a), "Is there a future for retailing on the Internet?", in Peterson, R.A. (Ed.), Electronic Marketing and the Consumer, Sage, Thousand Oaks, CA, pp. 139-154.

Jarvenpaa, S.L. and Todd, P.A. (1997b), "Consumer reactions to electronic shopping on the world wide web”, International Journal of Electronic Commerce, Vol. 1 No. 2, pp. 59-88.

Johnstone, M.-L., Ruane, L. and Wallace, E. (2013), "Generation Y females online: insights from brand narratives", Qualitative Market Research: An International Journal, Vol. 16 No. 3, pp. 315-335.

Kacen, J.J. and Lee, J.A. (2002), "The influence of culture on consumer impulsive buying behavior", Journal of Consumer Psychology, Vol. 12 No. 2, pp. 163-176.

Kaushik, V., Kumar, A., Gupta, H.. and Dixit, G. (2020), "Modelling and prioritizing the factors for online apparel return using BWM approach”, Electronic Commerce Research. doi: 10.1007/ s10660-020-09406-3.

Kautish, P. and Sharma, R. (2018), "Consumer values, fashion consciousness and behavioural intentions in the online fashion retail sector", International Journal of Retail and Distribution Management, Vol. 46 No. 10, pp. 894-914.

Kennedy, H.E., Baumann, S. and Johnston, J. (2019), "Eating for taste and eating for change: ethical consumption as a high-status practice", Social Forces, Vol. 98 No. 1, pp. 381-402.

Khalifa, M. and Limayem, M. (2003), "Drivers of internet shopping", Communications of the ACM, Vol. 46 No. 12, pp. 233-239.

Kilduff, P. (2005), "Patterns of strategic adjustment in the US textile and apparel industries since 1979", Journal of Fashion Marketing and Management: An International Journal, Vol. 9 No. 2, pp. 180-194.

Kim, D.E. and LaBat, K. (2013), "Consumer experience in using 3D virtual garment simulation technology", Journal of the Textile Institute, Vol. 104 No. 8, pp. 819-829.

Koon, O., Chan, R.Y.K. and Sharma, P. (2020), "Moderating effects of socio-cultural values on proenvironmental behaviors", Marketing Intelligence and Planning, Vol. 38 No. 5, pp. 603-618, doi: 10.1108/MIP-10-2019-0534.

Liang, J. and Xu, Y. (2018), "Second-hand clothing consumption: a generational cohort analysis of the Chinese market", International Journal of Consumer Studies, Vol. 42 No. 1, pp. 120-130.

Limayem, M., Khalifa, M. and Frini, A. (2000), "What makes consumers buy from Internet? A longitudinal study of online shopping”, IEEE Transactions on Systems, Man, and Cybernetics Part A: Systems and Humans, Vol. 30 No. 4, pp. 421-432.

Loker, S., Cowie, L., Ashdown, S. and Lewis, V.D. (2004), "Female consumers' reactions to body scanning”, Clothing and Textiles Research Journal, Vol. 22 No. 4, pp. 151-160.

Loker, S., Ashdown, S. and Carnrite, E. (2008), "Dress in the third dimension: online interactivity and its new horizons", Clothing and Textiles Research Journal, Vol. 26 No. 2, pp. 164-176.

MacCallum, R.C., Widaman, K.F., Zhang, S. and Hong, S. (1999), "Sample size in factor analysis", Psychological Methods, Vol. 4 No. 1, pp. 84-99.

Mahmoud, A.B., Fuxman, L., Mohr, I., Reisel, W.D. and Grigoriou, N. (2021), “'We aren't your reincarnation!" workplace motivation across $\mathrm{X}, \mathrm{Y}$ and $\mathrm{Z}$ generations", International Journal of Manpower, Vol. 42 No. 1, pp. 193-209, doi: 10.1108/IJM-09-2019-0448.

Marsh, H.W., Balla, J.R. and McDonald, R.P. (1988), "Goodness of fit indexes in confirmatory factor analysis: the effect of sample size”, Psychological Bulletin, Vol. 103 No. 3, pp. 391-410. 
Marsh, H.W., Kit-Tai, H., Balla, J.R. and Grayson, D. (1998), "Is more ever too much? The number of indicators per factor in confirmatory factor analysis", Multivariate Behavioural Research, Vol. 33 No. 2, pp. 181-220.

Matic, M. and Vojvodic, K. (2017), "Managing online environment cues: evidence from Generation Y consumers", International Journal of Electronic Marketing and Retailing, Vol. 8 No. 1, pp. 77-90.

Miell, S., Gill, S. and Vazquez, D. (2018), "Enabling the digital fashion consumer through fit and sizing technology", Journal of Global Fashion Marketing, Vol. 9 No. 1, pp. 9-23.

Mulyanegara, R.C. (2011), "The relationship between market orientation, brand orientation and perceived benefits in the non-profit sector: a customer-perceived paradigm”, Journal of Strategic Marketing, Vol. 19 No. 5, pp. 429-441.

Niemeier, S., Zocchi, A. and Catena, M. (2013), Reshaping Retail: Why Technology Is Transforming the Industry and How to Win in the New Consumer Driven World, John Wiley \& Sons.

Nwankwo, S., Hamelin, N. and Khaled, M. (2014), "Consumer values, motivation and purchase intention for luxury goods", Journal of Retailing and Consumer Services, Vol. 21 No. 5, pp. $735-744$.

Ogbuji, C.N. and Udom, A.O. (2018), "A holistic presentation of online shopping in Nigeria", Researchers World, Vol. 9 No. 3, pp. 22-33.

Pantano, E. and Viassone, M. (2015), "Engaging consumers on new integrated multichannel retail settings: challenges for retailers", Journal of Retailing and Consumer Services, Vol. 25, pp. 106-114.

Pavlou, P.A. (2002), "What drives electronic commerce? A theory of planned behavior perspective", Academy of Management Proceedings, Vol. 2002, pp. A1-A6.

Pentecost, R. and Andrews, L. (2010), "Fashion retailing and the bottom line: the effects of generational cohorts, gender, fashion fanship, attitudes and impulse buying on fashion expenditure", Journal of Retailing and Consumer Services, Vol. 17 No. 1, pp. 43-52.

Pepper, M., Jackson, T. and Uzzell, D. (2009), "An examination of the values that motivate socially conscious and frugal consumer behaviours", International Journal of Consumer Studies, Vol. 33 No. 2, pp. 126-136.

Renko, S. and Druzijanic, M. (2014), "Perceived usefulness of innovative technology in retailing: consumers' and retailers' point of view", Journal of Retailing and Consumer Services, Vol. 21 No. 5 , pp. 836-843.

Rohan, M.J. (2000), "A rose by any name? The values construct", Personality and Social Psychology Review, Vol. 4, pp. 255-277.

Scarpi, D. (2012), "Work and fun on the internet: the effects of utilitarianism and hedonism online", Journal of Interactive Marketing, Vol. 26 No. 1, pp. 53-67.

Schmidt, J., Dörner, K., Berg, A., Schumacher, T. and Bockholdt, K. (2015), The Opportunities in Online Luxury Fashion Sales are Rising, but what Do Consumers Expect from a Luxury Digital Experience, McKinsey \& Company, New Delhi.

Sima, C. (2016), "Generations BB, X, Y, Z, a-the changing consumer in the hospitality industry", in The Routledge Handbook of Hotel Chain Management, Routledge, pp. 497-505.

Singh, S. and Srivastava, S. (2019), "Engaging consumers in multichannel online retail environment: a moderation study of platform type on interaction of e-commerce and m-commerce", Journal of Modelling in Management, Vol. 14 No. 1, pp. 49-76, doi: 10.1108/JM2-09-2017-0098.

Song, H.K. and Ashdown, S.P. (2012), "Development of automated custom-made pants driven by body shape”, Clothing and Textiles Research Journal, Vol. 30 No. 4, pp. 315-329.

Song, J. and Zahedi, F. (2001), "Web design in e-commerce: a theory and empirical analysis", Proceedings of the 22nd International Conference on Information Systems, pp. 205-220.

Suh, B. and Han, I. (2003), "The impact of customer trust and perception of security control on the acceptance of electronic commerce", International Journal of Electronic Commerce, Vol. 7 No. 3, pp. 135-161. 
Suzuki, S. and Park, J. (2018), "Consumer evaluation of healthy, unpleasant-tasting food and the posttaste effect of positive information", Food Quality and Preference, Vol. 66, pp. 107-110.

Tan, M. and Teo, T.S.H. (2000), "Factors influencing the adoption of Internet banking", Journal of the Association for Information Systems, Vol. 1 No. 5, pp. 1-42.

Tan, K.L., Lew, T.Y. and Sim, A.K. (2019), "An innovative solution to leverage meaningful work to attract, retain and manage generation Y employees in Singapore's hotel industry", Worldwide Hospitality and Tourism Themes, Vol. 11 No. 2, pp. 204-216.

Tendai, M. and Crispen, C. (2009), "In-store shopping environment and impulsive buying", African Journal of Marketing Management, Vol. 1 No. 4, pp. 102-108.

Usman, M.U. and Kumar, P. (2020), "Factors influencing consumer intention to shop online in Nigeria: a conceptual study", Vision, pp. 1-8, doi: 10.1177/0972262920926797.

Varrella, S. (2020), "Demographics of Nigeria - statistics \& facts", Statista, available at: https://www. statista.com/topics/6477/demographics-of-nigeria/\#: :text=One $\% 20$ main $\% 20$ feature $\%$ 20which $\% 20$ characterizes,well $\% 20$ as $\% 20$ in $\% 20$ the $\% 20$ world.

Verma, V.K. and Chandra, B. (2018), "An application of theory of planned behavior to predict young Indian consumers' green hotel visit intention”, Journal of Cleaner Production, Vol. 172, pp. 1152-1162.

Xue, L., Parker, C.J. and Hart, C.A. (2019), "How to engage fashion retail with VR: a consumer perspective", 5th International AR and VR Conference, Munich, June 12-14th.

\section{Further reading}

Harrison, D.A., Mykytyn, P.P. and Riemenschneider, C.K. (1997), "Executive decisions about adoption of information technology in small business: theory and empirical tests", Information Systems Research, Vol. 8 No. 2, pp. 171-195.

Pantano, E. (2016), "Engaging consumer through storefront: evidences from integrating interactive technologies", Journal of Retailing and Consumer Services, Vol. 28, pp. 149-154.

Taylor, S. and Todd, P.A. (1995), "Understanding information technology usage: a test of competing models", Information Systems Research, Vol. 6 No. 2, pp. 144-176.

\section{Corresponding author}

Adenike Aderonke Moradeyo can be contacted at: nmoradeyo@pau.edu.ng

For instructions on how to order reprints of this article, please visit our website:

www.emeraldgrouppublishing.com/licensing/reprints.htm

Or contact us for further details: permissions@emeraldinsight.com 